INDONESIA ACCOUNTING JOURNAL

VOLUME 2, NUMBER 1, YEAR 2020

${ }^{1}$ Corresponding author

Jurusan Akuntansi

Fakultas Ekonomi dan Bisnis

Universitas Sam Ratulangi

Jl. Kampus UNSRAT

Manado, Indonesia, 95115

E-mail: jemotoh@gmail.com

${ }^{2,3}$ Jurusan Akuntansi

Fakultas Ekonomi dan Bisnis

Universitas Sam Ratulangi

Jl. Kampus UNSRAT

Manado, Indonesia, 95115

Article info:

Received 23 January 2020

Accepted 23 January 2020

Available online 24 January 2020

Keywords: accrual-based government accounting standards

JEL Classification: H11, H53

DOI: http://doi.org/10.3240o/iaj.27605

\section{Analisis penerapan Standar Akuntansi Pemerintahan untuk belanja pada Dinas Kesehatan Kota Manado}

Jefri Fanuel Motoh ${ }^{1}$

Jantje J. Tinangon ${ }^{2}$

Jessy D. L. Warongan ${ }^{3}$

\begin{abstract}
Government Accounting Standards is an accounting standard established to increase transparency in the management of state finances so that the use of state finance becomes more targeted and avoids various kinds of government financial misuse. The benefits of applying accrual-based Government Accounting Standards certainly make it easier for the government to evaluate financial reports on government performance, especially on human resources. The purpose of this study was to determine for expenditure at the Manado City Health Office in accordance with the application of accrual-bassed Government Accounting Standards. The results of the study on the Manado City in Public Health Agency have carried out the implementation of Government Accounting Standards for expenditure (cost realization), and accrual-based regulations have been implemented in accordance with the regulation of the Minister of Home Affairs Number 64 of 2013.
\end{abstract}

\section{Pendahuluan}

Era Revolusi Industri 4.0 merupakan suatu era yang sedang dialami oleh berbagai negara di masing-masing belahan dunia ini. Terlepas dari rotasi kurun waktu yang terus berjalan dan telah menjadikan perubahan dalam setiap segala aspek maupun bidang yang menjadi bagian perjalanan hidup masyarakat dunia itu sendiri, bangsa Indonesia yang sejatinya merupakan bagian dari masyarakat di dunia ini memiliki kewajiban berpartisipasi dan beradaptasi secara terus menerus dalam mewujudkan setiap aspek yang berlaku dalam pola berkehidupan ataupun bermasyarakat, misalnya dalam hal ini aspek pemerintahan.

Dalam hal menjalankan otonomi daerah sebagaimana diatur dalam Peraturan Pemerintah Nomor 18 Tahun 2016 tentang Perangkat Daerah, yang menyatakan bahwa pemerintah daerah adalah Kepala. Selain itu, dalam Peraturan Pemerintah Nomor 18 Tahun 2016 tentang Perangkat Daerah, menyatakan bahwa daerah otonom yang selanjutnya disebut daerah adalah kesatuan masyarakat hukum yang mempunyai batasbatas wilayah yang berwenang mengatur dan mengurus Urusan Pemerintahan dan kepentingan masyarakat dalam sistem Negara Kesatuan Republik Indonesia.

Dengan hadirnya otonomi daerah dalam bidang keuangan, pemerintah daerah mempunyai kebebasan untuk mengelola keuangan daerahnya sendiri. Hakekatnya pemerintah daerah bisa merencanakan sendiri, melaksanakan sendiri serta mempertanggungjawabkan sendiri setiap program sasaran ataupun segala aspek yang bertujuan mengelola kepemerintahan daerah itu sendiri. Banyaknya regulasi saat ini baik pemerintah pusat maupun daerah, baik ditingkat Kementrian maupun tingkat SKPD dituntut adanya 2 (dua) jenis pertanggungjawaban, yaitu: pertanggungjawaban keuangan dan pertanggungjawaban kinerja. Pemerintah 
daerah wajib mempertanggungjawabkan pelaksanaan APBD (Anggaran Pendapatan Belanja Daerah), baik dalam bentuk laporan keuangan maupun laporan kinerja. Laporan keuangan disusun dan disajikan sesuai dengan Standar Akuntansi Pemerintahan (SAP), sedangkan laporan kinerja disusun sesuai dengan peraturan pemerintah yang mengatur tentang laporan kinerja Instansi Pemerintah.

Perubahan di bidang akuntansi pemerintahan yang paling diinginkan adalah Standar Akuntansi Pemerintahan (SAP). Terbitnya SAP untuk dapat mewujudkan otonomi daerah yang lebih baik, juga merupakan jawaban atas penantian adanya pedoman pelaporan keuangan yang dapat diterima umum seperti yang telah diamanatkan oleh beberapa peraturan perundang-undangan. Penyusunan laporan keuangan yang berpedoman pada Standar Akuntansi Pemerintahan sesungguhnya adalah dalam rangka peningkatan kualitas laporan keuangan, sehingga dapat mewujudkan transparasi dan akuntabilitas pengelolaan keuangan pemerintah daerah.

Dinas Kesehatan yang menjadi salah satu Satuan Kerja Perangkat Daerah (SKPD) dari Pemerintahan Kota Manado merupakan bagian dalam salah satu pengguna anggaran, bahkan turut andil dalam setiap pelaporan keuangan serta harus membuat pertanggungjawaban atas kewenangan yang dilaksanakannya berdasarkan Peraturan Pemerintah Nomor 71 Tahun 2010 tentang Standar Akuntansi Pemerintahan yang kini telah direvisi kembali dan ditetapkan serta diberlakukannya Peraturan Menteri Dalam Negeri No. 64 Tahun 2013 tentang Penerapan Standar Akuntansi Pemerintah Berbasis Akrual pada Pemerintah Daerah.

Mengacu terhadap segala aspek permasalahan yang kemungkinan bisa terjadi ataupun bahkan saja telah hadir sebelumnya berhubungan dengan pembangunan nasional yang kini dilaksanakan secara terintregrasi, terstruktur dan berkesinambungan dalam halnya mewujudkan otonomi daerah yang lebih baik, disamping perlunya evaluasi ataupun langkah perubahan yang lebih baik lagi, diperlukan adanya kesadaran bagi pemerintah daerah terkait, sehingga otonomi daerah dapat berjalan lebih optimal dan pendapatan belanja daerah bisa dipergunakan dan dikeluarkan dalam setiap pembangunan daerah sebaik mungkin.

\section{Tinjauan pustaka}

Akuntansi. Menurut Kartikahadi (2016:3), "Akuntansi adalah suatu sistem informasi keuangan, yang bertujuan untuk menghasilkan dan melaporkan informasi yang relevan bagi berbagai pihak yang berkepentingan." Secara umum akuntansi dapat didefinisikan sebagai suatu sistem informasi yang berfungsi menyediakan informasi kuantitatif dari suatu unit organisasi atau kesatuan ekonomi yang ditunjukan kepada para pemakai sebagai dasar dalam pengambilan keputusan ekonomi. Secara bebas, akuntansi dapat didefinisikan sebagai aktivitas jasa yang dilakukan untuk mengukur, memproses dan mengkomunikasikan informasi keuangan satu unit organisasi atau kesatuan ekonomi untuk digunakan oleh para pemakai dalam pengambilan keputusan ekonomi.

Akuntansi berbasis akrual. Menurut KSAP (2006:3) Akuntansi Berbasis Akrual adalah suatu basis akuntansi dimana transaksi ekonomi dan peristiwa lainnya diakui, dicatat, dan disajikan dalam laporan keuangan pada saat terjadinya transaksi tersebut, tanpa memperhatikan waktu kas atau setara kas diterima atau dibayarkan. Sehingga waktu pencatatan (recording) akuntansi berbasis akrual sesuai dengan saat terjadinya arus sumber daya, agar dapat menyediakan informasi yang paling komprehensif karena seluruh arus sumber daya dicatat. Kerangka konseptual SAP Berbasis Akrual merupakan dasar pijak dalam penerapan kebijakan akuntansi pemerintah. Tanjung (2012:8) menjabarkan bahwa kerangka konseptual merumuskan konsep yang mendasari penyusunan dan pengembangan Standar Akuntansi Pemerintahan. KSAP bertugas menyusun standar akuntansi pemerintahan yang berlaku baik untuk pemerintah pusat 
maupun pemerintah daerah sesuai dengan kaidah-kaidah akuntansi yang berlaku umum. Dalam Keputusan Presiden RI Nomor 84 Tahun 2004 tentang Komite Standar Akuntansi Pemerintahan, SAP ditetapkan dalam Peraturan Pemerintah.

\section{Standar Akuntansi Pemerintahan}

Berbasis Akrual. Menurut Sujarweni (2015:1) Akuntasi Sektor Publik atau Akuntansi Pemerintahan adalah suatu aktivitas jasa yang terdiri dari mencatat, mengklasifikasikan, dan melaporkan atau transaksi ekonomi yang akhirnya akan menghasilkan suatu informasi keuangan yang akan dibutuhkan oleh pihak-pihak tertentu untuk pengambilan keputusan. Akuntansi pemerintahan di Indonesia dilandasi dengan standar akuntansi pemerintahan (SAP), yang juga disertai dengan pernyataan standar akuntansi pemerintahan (PSAP), buletin teknis (bultek) dan jika memungkinkan disertai juga interprestasinya. SAP dikukuhkan PP Nomor 71 Tahun 2010 tentang standar akuntansi pemerintah. Dalam Peraturan Menteri Dalam Negeri No. 64 tahun 2013 tentang Standar Akuntansi Pemerintahan Berbasis Akrual adalah SAP yang mengakui pendapatan, beban, aset, utang dan ekuitas dalam pelaporan finasial berbasis akrual, serta mengakui pendapatan, belanja, dan pembiayaan dalam pelaporan pelaksanaan anggaran berdasarkan basis yang ditetapkan oleh APBD. Perubahan perlakuan akuntansi pemerintah berbasis akrual akan membawa dampak/implikasi walau sekecil apapun, perubahan yang dianggap lebih baik ini bukan berarti hadir tanpa masalah (Simanjuntak, 2010). Praktek selama ini menunjukkan banyak kebijakan akuntansi disusun dengan menuliskan kembali hampir seluruh isi standar akuntansi pemerintahan. Praktek seperti ini menimbulkan inefisiensi karena adanya pengulangan (redundancy) antara SAP yang diatur oleh peraturan pemerintah dan kebijakan akuntansi yang diatur oleh peraturan kepala daerah. Oleh karena itu Peraturan Gubernur/Bupati/Walikota yang mengatur kebijakan akuntansi pemerintah daerah dapat mengambil unsur pokok dari SAP (Supriyadi et al., 2017).

Akuntansi Belanja. Menurut UndangUndang Republik Indonesia Nomor 33 Tahun 2004, belanja daerah adalah semua kewajiban daerah yang diakui sebagai pengurang nilai kekayaan bersih dalam periode tahun anggaran yang bersangkutan. Salah satu rangkaian prosedur dalam kegiatan proses transaksi atau tahapan yang menjadi bagian lingkup suatu satu kerja pemerintah. Dalam hal ini akuntansi belanja meliputi berbagai macam aspek atau poin tertentu, yakni meliputi pengakuan, pengukuran, penilaian, dan pengungkapan. Menurut Peraturan Pemerintah Nomor 71 Tahun 2010 tentang SAP, Laporan Realisasi Anggaran (LRA) menyebutnya dengan belanja, LRA sendiri disusun dan disajikan dengan menggunakan anggaran berbasis kas.

Penelitian Terdahulu. Pratiwi \& Pamungkas (2014) menemukan bahwa kebijakan akuntansi untuk pendapatan, belanja, dan pembiayaan daerah yang diterapkan oleh Pemerintah Daerah Kota Bogor sudah sesuai dengan PSAP No. 02 menurut PP Nomor 24 Tahun 2005 tentang Standar Akuntansi Pemerintahan (SAP). Kema (2013) menemukan bahwa Pemerintah Kota Manado pada Tahun 2011 dalam penyajian laporan keuangan belum mengacu pada SAP, terlihat pada pos bagi hasil kepada provinsi/kab/kota dan pemerintah desa pada pos belanja serta biaya dibayar dimuka pada aset lancar, tetapi secara keseluruhan laporan keuangan pemerintah Kota Manado telah berpedoman pada Standar Akuntansi Pemerintahan dengan menyajikan Laporan Realisasi Anggaran, Neraca, Laporan Arus Kas, dan Catatan atas Laporan Keuangan. Rintiani (2014) menemukan bahwa Kota Surabaya belum sepenuhnya menerapkan standar penyusunan laporan keuangan yang telah diatur pada PP nomor 71 tahun 2010. Beberapa ketidaksesuaian antara laporan keuangan pemerintah daerah Kota Surabaya dengan PP No 71 tahun 2010. Lamonisi (2016) menemukan bahwa pemerintah daerah tidak terkecuali pemerintah Kota Tomohon mempunyai kewajiban untuk 
dapat segera menerapkan peraturan pemerintah nomor 71 tahun 2010 mengenai standar akuntansi pemerintahan berbasis akrual.

\section{Metode penelitian}

Penelitian ini menggunakan metode kualitatif, dimana pemilihan metode diterapkan karena data nantinya akan dianalisa kembali serta diidentifikasi guna diuji guna memperoleh kesimpulan. Dengan menggunakan jenis metode penelitian kualitatif, hasil dari pencarian data-data kemudian akan dianalisis dan dideskripsikan setelah itu disimpulkan sesuai dengan rumusan masalah dan tujuan penelitian yang ingin dicapai.

Metode pengumpulan data yang digunakan dalam penelitian ini adalah dengan cara pengkajian kepustakaan yaitu mendapati bahan ataupun keterangan dari berbagai macam teori dengan cara menelaah serta membaca buku-buku referensi yang berkaitan dengan penelitian ini serta bahanbahan penjelasan lainnya yang berhubungan dengan materi yang kesemuanya itu didapati langsung dari Perpustakaan yang ada di Fakultas Ekonomi dan Bisnis Universitas Sam Ratulangi Manado. Dan disamping itu juga pengumpulan data diperoleh dari perkunjungan objek penelitian yakni Dinas Kesehatan Kota Manado untuk melakukan pengamatan secara langsung, melewati tahapan proses wawancara singkat kepada para informan serta pengambilan beberapa data untuk melengkapi informasi yang diinginkan.

Data yang diperoleh akan dianalisis dengan metode deskriptif, yaitu suatu metode yang bertujuan untuk membuat gambaran secara sistematis, faktual dan akurat mengenai fakta-fakta. Selain itu ciriciri jenis penelitian ini adalah bermaksud dengan membandingkan kesesuaian antara akuntansi belanja pada Dinas Kesehatan Kota Manado berdasarkan dengan Permendagri Nomor 64 Tahun 2013 tentang Penerapan Standar Akuntansi Pemerintah berbasis Akrual pada Pemerintah Daerah.

\section{Hasil penelitian dan pembahasan \\ Hasil penelitian}

Dari hasil pengamatan dan observasi yang telah dilakukan, diperoleh kajian-kajian dan beberapa data yang tentunya dapat dipaparkan pada hasil penelitian ini. Hal tersebut merupakan poin-poin yang berkaitan atau bahkan berkesinambungan dengan akuntansi belanja, yakni pengakuan, pengukuran, penilaian dan pengungkapan. Selain itu dari hasil penelitian juga, didapati sumber data yang terkait merupakan laporan realisasi anggaran belanja selama kurun waktu dari 5 (lima) tahun yang telah berlaku pada Dinas Kesehatan Kota Manado.

\section{Pengakuan Akuntansi Belanja.}

Dalam hal layanan umum, akuntansi belanja pada Dinas Kesehatan Kota Manado sendiri telah mengakui akuntansi belanja tersebut dengan mengacu pada peraturan perundangan yang mengatur mengenai badan layanan umum, hal ini dikemukan oleh Kepala Sub Bagian Keuangan dan Aset Fiktor Reinard Sinadia, SE. Sehubungan dengan dasar hukum pengakuan akuntansi belanja itu sendiri, dalam pelayanan umum, Achid $M$ yang merupakan petugas SIMDA (Sistem Informasi Daerah) pada Dinas Kesehatan Kota Manado menjelaskan bahwa, apapun yang diinput nantinya dalam aplikasi SIMDA terkait hal-hal pengakuan akuntansi belanja, semuanya telah mengacu pada ketetapan peraturan pemerintah dan telah diberlakukan sesuai dasar hukum yang telah diamanatkan.

2. Pengukuran Akuntansi Belanja. Dalam konteks pengukuran akuntansi belanja, belanja diukur jumlah pengeluaran kas yang keluar dari rekening kas umum daerah dan atau rekening bendahara pengeluaran. Dinas Kesehatan Kota Manado telah menetapkan dan memberlakukan acuan tersebut, hal tersebut kembali ditegaskan oleh Dewi Linda Angkouw yang menjadi pelaksana bendahara pengeluaran. Bendahara pengeluaran 
disamping mencatat setiap entitas laporan pengeluaran, tugas bendahara pengeluaran juga meliputi pengukuran setiap jumlah pengeluaran kas yang telah keluar rekening kas umum daerah/rekening bank yang dimiliki Dinas Kesehatan itu sendiri.

3. Penilaian Akuntansi Belanja. Terkait penilaian akuntansi belanja, Dinas Kesehatan Kota Manado selalu melakasanakan prosedur tersebut, mengingat belanja dinilai sebesar nilai tercatat dan disajikan pada laporan realisasi anggaran berdasarkan belanja langsung dan tidak langsung. Dewi Linda Angkouw selaku bendahara pengeluaran mengungkapkan bahwa belanja dinilai sebesar nilai tercatat seperti halnya ketika diberlakukan penilaian terhadap barang dan jasa yang sebelumnya akan dimasukkan dalam transaksi keuangan.

4. Pengungkapan Akuntansi Belanja. Penjelasan sebab-sebab tidak terserapnya target realisasi belanja daerah merupakan salah satu kewajiban terkait pengungkapan. Dari hasil informasi yang didapati dari saudara Fiktor R. Sinadia (Kasubbag Keuangan dan Asset) pengungkapan akuntansi belanja pada dasarnya sudah ditetapkan berdasarkan ketentuan yang berlaku, setiap adanya sebab-sebab yang membuat tidak terserapnya target realisasi belanja daerah tentu telah akan diungkapkan dalam laporan akhir tahun. Begitu juga yang disampaikan oleh petugas pelaksana SIMDA Achid M. ketika didapati beberapa anggaran yang tidak terserap dengan baik pada dasarnya hal tersebut nyatanya akan diungkapkan dalam laporan akhir tahun.

Tabel 1 menunjukkan Realisasi Anggaran Belanja, persentase realisasi, dan efisiensi biaya pada Dinas Kesehatan Kota Manado untuk tahun 2014 hingga tahun 2018.

$$
\begin{aligned}
\text { Persentase hasil realisasi terhadap biaya } & =\frac{\text { Realisasi (Belanja) }}{\text { Anggaran }} \times 100 \% \\
\text { Efisiensi biaya } & =100 \% \text {-Persentase realisasi }
\end{aligned}
$$

Tabel 1. Realisasi Anggaran dan Belanja Dinas Kesehatan Kota Manado

\begin{tabular}{clrrr}
\hline Tahun & Anggaran & $\begin{array}{l}\text { Realisasi } \\
\text { (Belanja) }\end{array}$ & $\begin{array}{c}\text { Realisasi Belanja } \\
(\mathbf{\%})\end{array}$ & \multicolumn{1}{c}{ Efisiensi Biaya } \\
\hline 2014 & 102.579 .841 .124 & 87.472 .192 .096 & $85,27 \%$ & $14,73 \%$ \\
2015 & 102.732 .052 .000 & 96.027 .823 .154 & $93,47 \%$ & $6,53 \%$ \\
2016 & 144.055 .657 .730 & 132.968 .788 .928 & $93,25 \%$ & $6,75 \%$ \\
2017 & 130.006 .391 .197 & 120.590 .817 .551 & $92,30 \%$ & $7,7 \%$ \\
2018 & 111.954 .588 .695 & 111.954 .588 .695 & $71,50 \%$ & $28,5 \%$ \\
\hline
\end{tabular}

Berdasarkan Tabel 1 maka perbandingan perbedaan anggaran dan realisasi belanja tersebut ke dalam bentuk grafik (bark chart) seperti yang disajikan pada Gambar 1 dengan tujuan agar semakin jelas melihat perbandingan anggaran dan realisasi. Gambar 1 menunjukkan bahwa perbandingan anggaran dan realisasi maka terlihat perbandingan anggaran yang ditetapkan dan seberapa besar pula hasil realisasi yang dapat dinyatakan.

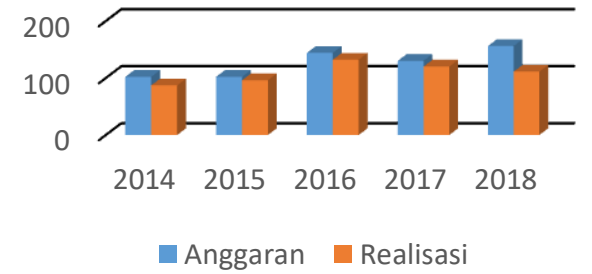

Gambar 1. Grafik Perbandingan Anggaran dan Realisasi 


\section{Pembahasan}

Pengakuan Akuntansi Belanja. Dinas Kesehatan Kota Manado sendiri nyatanya telah mengambil sikap langsung terhadap penetapan beberapa standar acuan terkait setiap prosedur yang ada, terlebih khusus dalam pengakuan akuntansi belanja yang semisalnya terjadi dalam lingkup perangkat daerah itu sendiri, standar acuan tersebut ialah regulasi ataupun peraturan pemerintah yang dikeluarkan oleh Pemerintah Daerah/Pusat. Dalam hasil penelitian sebelumnya yakni pengakuan akuntansi belanja yang memuat perihal persoalan hutang ataupun biaya yang harus diakui, terdapat kajian masalah apabila jika dalam waktu tertentu perangkat daerah Dinas Kesehatan Kota Manado telah menetapkan anggaran untuk pembelanjaan atas pengadaan kendaraan dan didapati belum atau tidak tersedianya dana operasional untuk membayar kewajiban yang harus dituntaskan, tapi pihak ketiga sudah menyetujui dan menyerahkan barang kendaraan tersebut, perihal hal tersebut perangkat daerah terkait melakukan pengakuan akan akuntansi belanja tersebut dan mengakui perihal tersebut sebagai hutang sesuai bukti memorial dan hal tersebut harus dipertanggungjawabkan atas pengeluaran yang telah terjadi, setelah itu dikonfimasi lagi kepada BUD (Bendahara Umum Daerah) terkait persoalan tersebut.

\section{Pengukuran Akuntansi Belanja.}

Dalam hasil penelitian membahas terkait terjadinya kenaikan gaji dalam waktu tertentu namun anggaran sebelumnya telah ditetapkan, hal ini perangkat daerah Dinas Kesehatan menjalankan tugasnya dengan tetap membayar gaji sesuai anggaran yang ditetapkan namun untuk kenaikan gaji, perangkat daerah ini menyerahkan pembayaran tersebut dalam APBD atau masuk dalam hutang yang akan dibayarkan di tahun periode berikunya. Terlepas dari hal tersebut, nyatanya Dinas Kesehatan Kota Manado telah menjalankan prosedur tahapan pengukuran akuntansi belanja itu sendiri berdasarkan ketentuan yang sudah berlaku dengan berlandaskan dasar hukum yang dikeluarkan pemerintah.
Penilaian Akuntansi Belanja. Apabila dalam suatu anggaran tercatat untuk pembelanjaan atas aset alat angkutan darat bermotor sebesar Rp. 1 Milyar, sewajarnya pengelola keuangan atau bendahara pengeluaran pun harus menilai dan mencatat hal tersebut dalam laporan realisasi anggaran sebesar nilai yang tercatat. Hal tersebut nyatanya salah satu perihal kajian yang telah diberlakukan oleh perangkat daerah Dinas Kesehatan Kota Manado, disamping membuktikan bahwa untuk penilaian akuntansi belanja itu sendiri telah diberlakukan dan ditetapkan dengan mengacu pada dasar hukum yang dikeluarkan oleh pemerintah terkait dapat juga diperoleh penilaian akuntansi belanja tersebut terhadap pembelanjaan barang modal yakni aset, serta didapatinya besar nilai penyusutan aset tersebut. Setelah melakukan penilaian terhadap nilai yang tercatat tentunya Dinas Kesehatan Kota Manado melakukan tahap berikutnya yaitu memasukkan nilai data tersebut dalam suatu laporan dan disajikan pada laporan realisasi anggaran berdasarkan belanja langsung ataupun tidak langsung.

Pengungkapan Akuntansi Belanja. Peninjauan kembali terkait pengungkapan akuntansi belanja yang dilaksanakan di Dinas Kesehatan Kota Manado, beberapa informan menyimpulkan hal yang sama terkait pengungkapan akuntansi belanja yaitu, ketika terjadi hal-hal yang membuat tidak terserapnya target realisasi belanja daerah hal tersebut harus diungkapkan dalam laporan akhir tahun, guna mengevaluasi kajian apa saja yang menjadi penyebab tidak terserapnya target realisasi.

Realisasi Anggaran Belanja Dinas Kesehatan Kota Manado. Realisasi anggaran belanja sesuai dengan Tabel 1 yang telah dipaparkan dengan jelas dapat kita lihat kenaikan presentase selama lima tahun terjadi peningkatan baik anggaran dan realisasi (belanja). Tahun 2014 daya serap anggaran adalah 85,27\%, tahun 2015 : $93,47 \%$, tahun $2016: 93,25 \%$, tahun 2017 : $92,30 \%$, tahun $2018: 71,50 \%$. Dalam realisasi daya serap anggaran yang dibuktikan pada persentase tidak mengalami 
defisit anggaran melainkan surplus, dalam hal ini rata-rata realisasi selama 5 tahun adalah $87,15 \%$. Terjadi efisiensi biaya selama lima tahun berkisar $64.21 \%$ dengan dengan rata-rata $12,84 \%$. Dengan adanya efisiensi biaya berarti penghematan anggaran dilakukan setiap tahun dengan rata-rata penghematan biaya selama lima tahun. Berdasarkan Gambar 1 dapat dilihat dengan jelas baik anggaran maupun belanja terjadi peningkatan terus menerus, meskipun pada tahun 2014 dan 2015 anggaran yang ditetapkan, kedudukannya hampir sama. Sedangkan di tahun 2017 terjadi penurunan anggaran yang mengakibatkan realisasi juga mengalami penurunan. Disamping itu realisasi (belanja) yang telah terjadi tidak mengalami penekanan anggaran. Dalam hal ini pengelolaan keuangan penuh kehatihatian berdasarkan petunjuk teknis dan petunjuk pelaksanaan kegiatan anggaran sehingga efisiensi biaya bisa tercapai.

\section{Kesimpulan dan saran Kesimpulan}

Dari ikhtisar hasil pembahasan penelitian tentang Analisis Penerapan Standar Akuntansi Pemerintah untuk Belanja pada Dinas Kesehatan Kota, yakni kesesuaian pemberlakuan akuntansi belanja berdasarkan SAP yang terdiri atas beberapa poin mengenai pengakuan, pengukuran, penilaian dan pencatatan. Dinas Kesehatan Kota Manado sendiri telah didapati hasil kajian yang diberlakukan telah sesuai dan sejalan berdasarkan acuan peraturan pemerintah dan telah diberlakukan berdasarkan dengan regulasi Peraturan Menteri Dalam Negeri No 64 Tahun 2013 tentang penerapan SAP berbasis Akrual pada pemerintah daerah.

\section{Saran}

Adapun saran penelitian ini kepada instansi pemerintah terkait yakni Dinas Kesehatan Kota Manado adalah dengan adanya tugas dan peran setiap pelaksana masing-masing petugas, agar kiranya selalu memonitoring pedoman regulasi terbaru pemerintah, memahami setiap aspek dasar hukum dan menjalankan kewajibannya dengan berpedoman pada standar operasional prosedur yang berlaku serta diiringi pemahaman lebih dalam lagi terkait standar akuntansi pemerintah daerah yang sudah disahkan dan diberlakukan.

\section{Daftar pustaka}

Kartikahadi, H. (2016). Akuntansi keuangan berdasarkan SAK berbasis IFRS, Edisi 2 Buku 1. Jakarta: Ikatan Akuntan Indonesia.

Kema, I. (2013). Penyajian laporan keuangan daerah berdasarkan Standar Akuntansi Pemerintahan pada Pemerintah Kota Manado. Jurnal EMBA: Jurnal Riset Ekonomi, Manajemen, Bisnis dan Akuntansi, 1(3), 771-781. https://ejournal.unsrat.ac.id/index.php/emba/a rticle/view/2215

Keputusan Presiden Republik Indonesia No. 84 Tahun 2004 tentang Komite Standar Akuntansi Pemerintahan. Jakarta.

KSAP. (2006). Memorandum pembahasan penerapan basis akrual dalam akuntansi pemerintahan di Indonesia. Jakarta. http://www.ksap.org/memorandum.pdf

Lamonisi, S. (2016). Analisis penerapan standar akuntansi berbasis akrual pada Pemerintah Kota Tomohon. Jurnal EMBA: Jurnal Riset Ekonomi, Manajemen, Bisnis dan Akuntansi, 4(1), 223-230. https://ejournal.unsrat.ac.id/index.php/emba/a rticle/view/11592

Peraturan Pemerintah Republik Indonesia No. 18 Tahun 2016. Tentang Perangkat Daerah. Jakarta.

Peraturan Pemerintah Republik Indonesia No. 71 Tahun 2010. Tentang Standar Akuntansi Pemerintahan. Jakarta.

Peraturan Menteri Dalam Negeri No. 64. Tahun 2013. Tentang Penerapan Standar Akuntansi Pemerintahan Berbasis Akrual pada Pemerintah Daerah. Jakarta.

Pratiwi \& Pamungkas. (2014). Analisis Pengakuan Pendapatan, Belanja, dan Pembiayaan Daerah pada Pemerintah Daerah Kota Bogor. Jurnal Ilmiah Akuntansi Kesatuan, 2(1), 59-72. https://www.researchgate.net/publication/3259 86480_Analisis_Pengakuan_Pendapatan_Belanja _Dan_Pembiayaan_Daerah_Pada_Pemerintah_ Daerah_Kota_Bogor

Rintiani, N. W. (2014). Evaluasi penyajian laporan keuangan Pemerintah Daerah Kota Surabaya berdasarkan Peraturan Pemerintah No. 71 tahun 2010. Jurnal Akuntansi AKUNESA, 3(1), 1-25. https://jurnalmahasiswa.unesa.ac.id/index.php/j urnal-akuntansi/article/view/11232

Simanjuntak, B. (2010). Penerapan Akuntansi Berbasis Akrual di Sektor Pemerintahan di Indonesia. Jakarta: Kongres XI IAI. https://www.scribd.com/doc/76222442/Binsar -Paper-Kongres-Iai-9-Des-Implementasi-Akrual

Sujarweni. (2015). Akuntansi sektor publik. Yogyakarta: Pustaka Baru Press.

Supriyadi, B., Suwarda, D., \& Manghayu, A. (2017). Kebijakan akuntansi akrual pemerintahan daerah. Bogor: Penerbit Ghalia Indonesia. 
Tanjung, A. H. (2012). Akuntansi pemerintahan berbasis akrual pendekatan teknis sesuai PP No. 71/2010. Bandung: Alfabeta.

Undang-Undang Republik Indonesia. No. 33 Tahun 2004.

Tentang Perimbangan Keuangan Antara Pemerintah Pusat dan Pemerintah Daerah. Jakarta. 